УДК 616.314. 17. 002. 3 - 031. $82-018.74$

\title{
ЕНДОТЕЛІАЛЬНА ДИСФУНКЦІЯ СУДИН ПАРОДОНТА ПРИ ГЕНЕРАЛІЗОВАНОМУ ПАРОДОНТИТІ
}

Світлана Різник кандидат медичних наук, доцент, Львівський медичний інститут

Юрій Різник кандидат медичних наук, Львівський національний медичний університет ім. Данила Галицького

Тетяна Пиндус доктор медичних наук, Львівський медичний інститут

Володимир Пиндус кандидат медичних наук, Львівський медичний інститут

Svitlana Riznyk Candidate of Medical Sciences, Associate Professor, Lviv Medical Institute https://orcid.org/0000-0002-3557-1984

Yuriy Riznyk Candidate of Medical Sciences, Danylo Halytsky Lviv National Medical University https://orcid.org/0000-0001-9611-1175

Tetyana Pyndus Doctor of Medical Sciences, Associate Professor, Lviv Medical Institute https://orcid.org/0000-0002-2283-9750

Volodymyr Pyndus Candidate of Medical Sciences, Lviv Medical Institute https://orcid.org/0000-0002-2463-082X 


\section{ENDOTHELIAL DYSFUNCTION OF PERIODONTAL VASCULATURE OF GENERALIZED PERIODONTITIS}

\section{ABSTRACT}

The development of the pathological process in patient with generalized periodontitis accompanied by increased levels of ET-1 and proinflammatory cytokines such as TNF $-\alpha, \mathrm{IL}-1 \beta, \mathrm{IL}-6$ in oral fluid, which are the markers of endothelial dysfunction and contribute to the progression of inflammatorydystrophic process in the periodontal tissues. The mechanism of the pathogenetic correlations justifies a scientific approach to the selection and usage of immunological research methods in patients with generalized periodontitis.

All this testifies to a significant violation of hemodynamics of periodontal disease. Structural changes of blood capillaries with intravascular are revealed blood clotting is the basis for the appointment of such patients with prophylactic and curative anticoagulants.

Key words: generalized periodontitis, endothelium, dysfunction, endothelin1, pro-inflammatory cytokines, IL $-1 \beta, \mathrm{IL}-6, \mathrm{TNF}-\alpha$, ultrastructure of blood capillaries.

Вступ. Важливим досягненням у вирішенні патогенезу генералізованого пародонтиту стало вивчення дисфункцій ендотелію судин мікроциркуляторного русла пародонта, яка характеризується порушеною ендотелій залежною релаксацією судин i підвищеною адгезивністю ендотелію [2, 3, 4, 11].

Особлива увага приділяється вивченню гемомікроциркуляторних порушень, які ведуть до розвитку в пародонті метаболічних порушень, дистрофічних, дегенеративних змін, ініціюють запальні реакції $[1,5,6,7,9$, 12]. Оцінка ендотеліальної дисфункції є новим і перспективним напрямком сучасної медицини і розглядається не тільки як маркер судинних порушень. Встановлено іiі важливе значення в ініціюванні, прогресуванні і клінічних проявах чисельних захворювань $[2,4,8,10,11]$. В пародонтології механізми 
розвитку ендотеліальної дисфункції вивчені недостатньо, що вказує на необхідність глибокого вивчення цієї проблеми на сучасному медичному рівні.

Мета роботи. Вивчити роль ендотеліальної дисфункції (ЕД) мікроциркуляторного русла пародонта в розвитку i прогресуванні генералізованого пародонтита (ГП) за допомогою клініко-морфологічних змін його судинної системи та імунологічних порушень.

Матеріали та методи. Проведені клінічні та імунологічні дослідження 85 пацієнтів віком 25-50 років. 3 них 15 осіб були із клінічно інтактним пародонтом (група порівняння), 71 особа - хворі ГП (основна група). Відповідно до систематики хворіб пародонта М.Ф. Данилевського у 29 обстежених діагностували ГП початкового і I ступеня, у 25 хворих - II ступеня, у 17 осіб - III ступеня. Пародонтологічний статус вивчали за загально прийнятими в стоматології методами, включаючи ортопантомографію.

Об’єктом імунологічних досліджень була ротова рідина (РP), яку збирали вранці натще шляхом спльовування у стерильні пробірки. Отримані субстрати центрифугували при 3000 об./хв., впродовж 15 хвилин. Для дослідження використовували надосадову рідину, яку зберігали у морозильній камері при температурі - 20․ Супернатанти досліджували після розмороження 3 використанням імуноферментних аналізаторів STAT FAX 303 plus. Концентрацію ендотеліна-1 (ЕТ-1) (маркера ендотеліальної дисфункції ЕД) визначали за допомогою набору реактивів Endotelin-1 «Biomedica» (Австрія), а рівень ІЛ - 1 $\beta$, ІЛ - 6, ФНП - $\alpha$ наборами реактивів виробництва фірми «Diaclone» (Франція).

Статистичне опрацювання результатів досліджень проводила за допомогою пакета прикладних програм «Microsoft Office Excel». Показник вірогідності оцінювали за t-критерієм Стьюдента.

Вивчення ультраструктурних змін кровоносних капілярів ясен проводилось у 15 хворих ГП без супутньої патології віком 35-50 років. 
Група порівняння складалась із 5 практично здорових осіб із клінічно інтактним пародонтом.

В якості матеріалу для електронно-мікроскопічних досліджень використовували ясенну тканину, отриману під час кюретажу пародонтальних кишень та видалення зубів. Біоптати ясен фіксували у 2\% розчині чотирьох окису осмію на 0,1 м фосфатному буфері, заливали в суміш епон-аралдит. Ультратонкі зрізи проводили на ультрамікротомі (УМТП-3М), дослідження і фотографування - на електронному мікроскопі УЕМВ-100 К.

Результати дослідження та їх обговорення. Порушення балансу між утворенням вазодилататорів і вазоконстрикторів у бік збільшення останніх, $\epsilon$ проявом ЕД судин пародонта i веде до прогресування дистрофічнозапального процесу пародонта.

При наявності пошкодження ендотелія страждає вазорелаксація, через ослаблення чи зупинку утворення оксиду азота і домінує вазоконстрикція, зумовлена посиленою секрецією ендотеліально-залежних констрикторних чинників, про що свідчить рівень ЕТ-1 у обстежених хворих.

Проведено аналіз концентрації ЕТ-1 у обстежених хворих ГП у залежності від тяжкості і перебігу захворювання.

Максимальна концентрація ЕТ-1 визначалась в РР хворих ГП ІІІ ступеня в період загострення симптоматичного гінгвіту і становила 1,28 \pm 0,006 фмоль/мл, що втричі перевищувало рівень ЕT-1 в групі порівняння ( $\mathrm{P}<0,001)$ (Табл. 1).

Збільшення концентрації ЕТ-1 впливає на проліферацію ендотелія, сприяє вазоспазму та тромбоутворенню, а також прогресуванню дистрофічно-запального процесу в пародонтальних тканинах.

Отриманні результати досліджень дали змогу оцінити цитокіновий статус у хворих на ГП залежно від ступеня тяжкості та перебігу захворювання. У ході дослідження виявлено підвищення рівнів прозапальних цитокінів ІЛ - $1 \beta$, ІЛ - 6 , ФНП - $\alpha$ у РР в усіх групах хворих на ГП, порівняно 3 аналогічними показниками РР пацієнтів із клінічно інтактним пародонтом 
(Табл. 1). Порівнюючи вміст прозапальних цитокінів у групах із різним перебігом і ступенем тяжкості ГП, встановлено вищі їх рівні у період загострення ГП при II і особливо III ступені тяжкості захворювання, зокрема, визначено прямий кореляційний зв'язок між ступенями ГП і вмістом ФНП $\alpha(\mathrm{r}=+0,55)$ (Табл. 1$)$.

Оскільки ФНП - $\alpha$ підсилює експерсію молекул адгезії на поверхні ендотелію, активує макрофаги, нейтрофіли та зумовлює синтез білків гострої фази запалення $[3,5,9,13]$, то його дія спрямовувалась на розвиток запальної реакції в тканинах пародонта для ефективного усунення бактерійного агента.

Для розуміння ролі ІЛ - $1 \beta$ та ІЛ - 6 в деструкції тканин пародонта, ми оцінили рівні цих двох показників у РР хворих на ГП і у пацієнтів 3 інтактним пародонтом. Концентрація ІЛ - $1 \beta$ в РР найнижчою була у хворих на хронічний ГП І ступеня і становила $197 \pm 15$ пг/мл (P < 0,05), що в 4,5 рази перевищувало показник групи порівняння (149 \pm 16 пг/мл). Тоді як у хворих на ГП III ступеня в період загострення захворювання цей показник перевищував аналогічний групи порівняння в 4 рази (Табл. 1). Саме збільшення кількості ІЛ - $1 \beta$ стало чіткою специфічною особливістю захисних механізмів запального процесу в тканинах пародонта. Отже, швидкість активації продуцентів цього цитокіну (моноцитами, макрофагами, епітеліальними клітинами), супроводжувались високою концентрацією ІЛ $1 \beta$ в РР хворих на ГП.

Концентрація ІЛ - 6 в РР найнижчою була у хворих на хронічний ГП I ступеня і становила 22,3 $\pm 2,1$ пг/мл (Р < 0,001), що в три рази перевищувало показники групи порівняння (Табл.1).

Співставлення отриманих результатів із ступенем тяжкості та періодами загострення ГП свідчать, що прогресування ГП супроводжується гіперпродукуванням маркерів ЕД судин: потужного вазоконстриктора ЕТ-1, факторів гуморального імунітета прозапальних цитокінів ІЛ - $1 \beta$, ІЛ -6 , ФНП - $\alpha$ в РР хворих на ГП, що свідчить про активування процесів деструкції пародонтальних тканин. 
При електронно-мікроскопічних дослідженнях у хворих 3 I ступенем ГП зміни в гемомікроциркуляторному руслі ясен суттєво відрізнялись від контрольних досліджень. Вони проявились в порушенні базальної мембрани кровоносних капілярів, гіпертрофії ендотелія, дегенеративних змінах цитоплазматичних мембран та у підвищеній схильності еритроцитів до адгезії та гемолізу. Внаслідок цих змін виникав стаз крові, адгезія та внутрішньокапілярний гемоліз еритроцитів.

Еритроцити при ГП втрачають здатність деформуватись і вільно проходити через капіляри. Вказані зміни ведуть до сповільнення мікрогемодинаміки, агрегації клітин крові.

При II і III ступенях ГП спостерігались значні зміни капілярів. Їх базальна мембрана розпушувалась по периметру, виникав мікроклазматоз цитоплазматичних виступів. При загостренні ГП виникав гемоліз еритроцитів, дегрануляція тромбоцитів, просвіт капілярів звужувався у поєднанні з реологічними змінами.

Апоптоз ендотеліоцитів міг відбутись під впливом протизапальних цитокінів (ІЛ - $1 \beta$, ІЛ - 6, ФНП - $\alpha$ ), вільних радикалів, які декретують активовані макроси.

Активовані Т-лімфоцити теж продукують цитокіни, які здатні викликати апоптоз клітин.

Згідно 3 нашим дослідженням, моноцити-макрофаги, лімфоцити часто перекривали звужений просвіт капілярів. Секретуючи ЕT-1 і прозапальні цитокіни вони спонукають до загострення та прогресування ГП.

\section{ВИСНОВКИ}

Розвиток патологічного процесу у хворих генералізованим пародонтитом супроводжується підвищенням концентрації $\mathrm{ET}-1$ i прозапальних цитокінів ІЛ $-1 \beta$, ІЛ -6 , ФНП - $\alpha$ в ротовій рідині, які $\epsilon$ маркерами ЕД і сприяють прогресуванню дистрофічно-запального процесу в пародонті. Кількість циркулюючих в РР маркерів ЕД знаходиться в прямій кореляційній залежності із ступенем тяжкості та періодами загострення ГП. 
Ультраструктурні порушення кровоносних капілярів ясен при ГП проявляються в гіперплазії ендотеліальних клітин, деструкцій органел, перипапілярного простору, розпушенні базального шару.

Збільшується кількість сладжованих тромбоцитів, еритроцитів 3 явищами гемолізу, формуються мікротромби, що свідчить про значне порушення мікрогемодинаміки пародонта.

\section{СПИСОК ВИКОРИСТАНИХ ДЖЕРЕЛ}

1. Вольф Г.Ф. Пародонтология/ Г.Ф. Вольф, Э.М. Ратейцхак, К. Ратейцхак; пер. с нем.: под ред. проф. Г.М. Барера. - М.: МЕДпресс-информ. 2008. $548 \mathrm{c}$.

2. Гомазков О.А. Эндотелин в кардиологии: молекулярные, физиологические и патологические аспекты/ О.А. Гомазков// Кардиология. 2001. №2. c. $50-58$

3. Гильямиров Э.М. Клинико-метаболическая база по хроническому генерализованому пародонтиту/ Э.М. Гильямиров, В.П. Бережной// Стоматология. 2008. №5. с. 23-26

4. Коркушко О.В. Эндотелиальная дисфункция. Клиничиские аспекты пробмемы/ О.В. Коркушко, В.Ю. Лигиневская// Кровообіг та гемостаз. 2003. №2. c. $4-15$

5. Мащенко И.С. Обмен цитокинов у больних генерализованным пародонтитом/ И.С. Мащенко// Современная стоматология. 2004. № 1. с. 73 75

6. Михалева Л.М. Ультраструктурная характеристика сосудов микроциркуляторного русла десин при хроническом пародонтите// Л.М. Михалева, Т.Г. Бархина, В.Д. Шаповалов// Архив патологии. 2002. №2. с. 4548

7. Ярова С.П. Роль судинних змін у розвитку і перебігу генералізованого пародонтиту/ С.П. Ярова, Н.В. Мозгова// Український стоматологічний альманах. 2004. №3-4. с. 23-26 
8. Cosentino F/ Endothelial dysfunction in hyperteusiou/ F/ Cosentino, J. Luscher. Milano: Gragiche Sezenissima. 2003. 52 p.

9. Ebersole J. Systemic humoral immune responses in periodontal disease/ J. Ebersole// Crit. Rev. Oral. Biol. Med. 2009. №1. p. 283-331

10. Genco R. Host responses in periodontal diseases: Current concepts/ R. Genco// J. Periodontol. 2002. Vol. 63. №2. p. 335-355

11. Halcox J. Endothelial dysfunction and prognosis curculation/ J. Halcox// Curculalion. 2002. Vol. 106. p. 653-659

12. Hetz J. Пародонтология сегодня/ J. Hetz// Новое в стоматологии. 2001. T. 4.2. c. $39-48$

13. Manchini G. Smmunochemical guantitation of antigeus by single rablial immunodiffision/ G. Manchini// Immunochemistry. 1999. Vol. 2, №6. p. 234-236

Таблиця 1.

\section{Імунологічні показники ротової рідини у хворих} генералізованим пародонтитом (M $\pm \mathbf{m})$

\begin{tabular}{|c|c|c|c|c|c|}
\hline \multicolumn{2}{|c|}{ Діагноз } & $\begin{array}{c}\text { ЕТ - 1, } \\
\text { фмоль/мл }\end{array}$ & $\begin{array}{c}\Phi Н П-\alpha, \\
\text { Пг/мЛ }\end{array}$ & $\begin{array}{c}\text { IЛ }-1 \beta, \\
\text { Пг/мЛ }\end{array}$ & $\begin{array}{l}\text { ІЛ -6, } \\
\text { ПГ/мЛ }\end{array}$ \\
\hline \multicolumn{2}{|c|}{ Інтактний пародонт (n = 15) } & $0,42 \pm 0,03$ & $7,85 \pm 0,87$ & $149 \pm 16$ & $12,9 \pm 0,7$ \\
\hline \multirow{2}{*}{$\begin{array}{l}\text { ГП початкового } \\
\text { i I ступеня } \\
(\mathrm{n}=29)\end{array}$} & $\begin{array}{l}\text { загострення } \\
(\mathrm{n}=13)\end{array}$ & $\begin{array}{l}0,64 \pm 0,05 \\
P<0,01\end{array}$ & $\begin{array}{l}11,5 \pm 1,1 \\
P<0,05\end{array}$ & $\begin{array}{l}205 \pm 21 \\
P<0,05\end{array}$ & $\begin{array}{l}24,7 \pm 1,4 \\
P<0,001\end{array}$ \\
\hline & $\begin{array}{l}\text { хронічний } \\
(\mathrm{n}=16)\end{array}$ & $\begin{array}{l}0,59 \pm 0,04 \\
P<0,01\end{array}$ & $\begin{array}{l}10,9 \pm 1,1 \\
P<0,05\end{array}$ & $\begin{array}{l}197 \pm 15 \\
P<0,05\end{array}$ & $\begin{array}{l}22,3 \pm 2,1 \\
P<0,01\end{array}$ \\
\hline \multirow{2}{*}{$\begin{array}{l}\text { ГП ІІ ступеня } \\
(\mathrm{n}=25)\end{array}$} & $\begin{array}{l}\text { загострення } \\
(\mathrm{n}=12)\end{array}$ & $\begin{array}{l}1,0 \pm 0,04 \\
P<0,001\end{array}$ & $\begin{array}{l}12,6 \pm 1,5 \\
P<0,05\end{array}$ & $\begin{array}{l}587 \pm 37 \\
P<0,001\end{array}$ & $\begin{array}{l}31,8 \pm 2,5 \\
P<0,001\end{array}$ \\
\hline & $\begin{array}{l}\text { хронічний } \\
(\mathrm{n}=13)\end{array}$ & $\begin{array}{l}0,8 \pm 0,07 \\
\mathrm{P}<0,001\end{array}$ & $\begin{array}{l}12,3 \pm 1,5 \\
P<0,05\end{array}$ & $\begin{array}{l}256 \pm 35 \\
P<0,05\end{array}$ & $\begin{array}{l}29,8 \pm 2,9 \\
P<0,001\end{array}$ \\
\hline $\begin{array}{l}\text { ГП, III ступеня } \\
(\mathrm{n}=17)\end{array}$ & $\begin{array}{l}\text { загострення } \\
(\mathrm{n}=8)\end{array}$ & $\begin{array}{l}1,28 \pm 0,06 \\
P<0,001\end{array}$ & $\begin{array}{l}19,9 \pm 2,4 \\
P<0,001\end{array}$ & $\begin{array}{l}659 \pm 42 \\
P<0,001\end{array}$ & $\begin{array}{l}39,0 \pm 3,5 \\
P<0,001\end{array}$ \\
\hline
\end{tabular}




\begin{tabular}{|l|l|l|l|l|}
$\begin{array}{l}\text { хронічний } \\
(\mathrm{n}=9)\end{array}$ & $\begin{array}{l}0,94 \pm 0,07 \\
\mathrm{P}<0,001\end{array}$ & $\begin{array}{l}16,5 \pm 2,5 \\
\mathrm{P}<0,001\end{array}$ & $\begin{array}{l}301 \pm 35 \\
\mathrm{P}<0,01\end{array}$ & $\begin{array}{l}16,5 \pm 1,8 \\
\mathrm{P}<0,001\end{array}$
\end{tabular}

Примітка:

$\mathrm{P}$ - показник вірогідності різниць у порівнянні 3 пацієнтами з інтактним пародонтом. 